\title{
Breast Cancer Pathologic TNM Finding v8
}

National Cancer Institute

\section{Source}

National Cancer Institute. Breast Cancer Pathologic TNM Finding v8. NCI Thesaurus. Code C139408.

A pathologic finding about one or more characteristics of breast cancer, following the rules of the TNM AJCC v8 classification system. 